\title{
From the President
}

Pauletta Brown Bracy, President

Hes centennial may happen only once in a lifetime. It inspires reflection and remembrance of the past, and envisioning the future. I am honored to highlight a few of many developments in each decade of NCLA's history from the North Carolina Library Association Centennial Handbook, 1904-2004, prepared by Al Jones, North Carolina Libraries Editor.

$1900 \mathrm{~s}$

- Three women and four men founded NCLA in 1904 in Greensboro at the State Normal and Industrial College. The first annual meeting was held in November in Charlotte of the same year.

- The American Library Association met jointly with NCLA in Asheville, and NCLA became formally affiliated with ALA. 1910s

- District meetings were organized to cope with war-time

Milestones and Memories: The Centennial Celebration

1940s

- The first issue of North Carolina Libraries was published.

1950 s

- Two of the founders, Louis Round Wilson and R.D. Douglas, attended the fiftieth anniversary celebration in High Point. NCLA and NCNLA merged.

1960s

- North Carolinians for Better Libraries, a statewide citizens' committee, was organized to assist in the formation or revitalization of committees for better libraries and to coordinate their activities with such existing groups as Friends of Public Libraries.

1970s

- The first Governor's Conference on Libraries and Information Services was sponsored by NCLA and the State Library in 1978. Delegates were elected to represent North Carolina at the White House Conference the following year.

- The membership endorsed passage of the Equal Rights Amendment in 1979.

1980 s

- The Friends of North Carolina Public Libraries held its first annual meeting at the Lee County Library in Sanford.

- North Carolina Libraries was awarded the H.W. Wilson Library Periodical Award by ALA in 1981, and also in 1992 and in 1994.

- The Executive Board established the biennial NCLA Distinguished Library Service Award which was first presented in 1989.

- A permanent office of the association was established.

1990s

- Nine regional Governor's Conferences were held during 1990 in preparation for the White House Conference on Library and Information Science held the next year.

- The NCLA membership listserv was established in 1995; and in 1996, the NCLA Web Page was developed.

- The first NCLA Leadership Institute was held in 1996. Subsequent ones have been in 1998, 2001, and 2002.

- The NCLA Endowment Fund was established.

2000 s

- The Executive Board passed a nondiscrimination policy regarding vendor contracts, and a resolution in support of ALA's legal action against the Children's Internet Protection Act (CIPA).

- NCLA engaged its first lobbyist to address concerns about Internet filtering bills before the North Carolina General Assembly.

- The Commission on the Future of Libraries and the Book, appointed in 2002, released its findings in Spring 2004.

The foresight of NCLA's founders is phenomenal. The record reveals a proactive and productive organization poised for another century of service. 